\title{
European narratives and the politicisation of the EU: Gone with the Wind or Game of Thrones?*
}

\author{
Luis Bouza García \\ Coordinador Académico de las asignaturas de Estudios Generales \\ del Colegio de Europa en Brujas
}

\begin{abstract}
Sumario: I. Introduction. - II. Narratives in the fragmented European public sphere.-III. European narratives and politics: consensus versus competition?-IV. How do stories circulate in the fragmented European public sphere? 1. Deepening versus widening: the contentious case of Turkey. 2. Narratives of economic integration: the contentions governance of the Euro-zone.-V. Conclusion.-VI. References.
\end{abstract}

\begin{abstract}
This article engages with a recent academic fashion which tends to see the lack of a suggestive narrative as one of the reasons of the EU's distance with the public . The most recent version of this approach suggests that this is related to the generational fact that most living Europeans have never known war, the main reason that drove European states to start the integration process. The article engages how the «narrative turn» is being applied to the European Union and suggests that in its current form it is ignoring the ongoing debate on the politicisation of the EU. This is because the narrative approach seems to perpetuate the «permissive consensus» which used to characterise European integration in the 60s and 70s. The article is sceptical on such approach. It rather points out that the EU has already some clearly cleaved narratives on key issues such as enlargement and economic integration. The article examines the opposing narratives in these fields and suggests that they have the potential to politicise approaches to the EU and that although alternative narratives often fail to engage each other, the plurality of narratives is a sign of a stronger, not a weaker political salience of EU affairs.
\end{abstract}

Keywords: European Union, narratives, democracy, politicisation, enlargement, growth, austerity.

Resumen: Este artículo analiza una corriente académica reciente que relaciona el alejamiento de la UE de los ciudadanos con su incapacidad de producir un relato sugerente. La versión más reciente de este enfoque señala que la falta de dicho relato se explica por un cambio generacional que hace que la mayoría de los europeos no hayan conocido la principal razón que llevó a los Estados europeos a iniciar el proceso de integración: la guerra. El artículo discute la aplicación del «giro narrativo» a la Unión Europea y señala que dicho enfoque ignora el debate

* Recibido 21 de mayo de 2013, aceptado 9 de julio de 2013. 
actual sobre la politización de la UE. Esto se debe a que el enfoque narrativo parece intentar reconstruir el "consenso permisivo» que caracterizaba a la integración europea en los años 60 y 70. El artículo se muestra escéptico sobre el posible resultado de dicho enfoque. Sin embargo también señala que ya existen algunos relatos europeos claramente diferenciados en temas clave como la ampliación y la integración económica. Se examinan relatos contrapuestos en estas políticas y se señala que tienen el potencial de politizar el discurso. Aunque con frecuencia los relatos no entren en oposición, la propia diversidad de relatos sobre la UE que se constata es indicativa de que los ciudadanos reclaman no menos sino más participación y control en los asuntos comunitarios.

Palabras clave: Unión Europea, narrativas, democracia, politización, ampliación, crecimiento, austeridad.

\section{Introduction}

A recent event convened by president Barroso launched a high level political and institutional reflection on «A new narrative for Europe»:

«We must also recognise that, while our Europe arose 60 years ago from the reconciliation between long-standing enemies, it must now find a fresh impetus in a new rapprochement, by which I mean a coming together between the people of Europe and the European Union» ${ }^{1}$.

For years Europe has succeeded at producing peace, stability and foster economic cooperation and growth in the continent. These goals were paramount for the generations that lived through the World Wars and the Cold war. Nevertheless today younger generations fortunately ignore the experience of war and show no appreciation of the public goods that the EU produces for them, with 2 persons out of 3 under 35 abstaining in the 2009 European elections ${ }^{2}$. This is why a turn in the academic literature and political debate argues that the EU needs to find a new political narrative that reconnects with the current need of Europeans.

1 BARROSO, J.M., «A new narrative for Europe» SPEECH/13/357, Palais des Beaux Arts, Brussels, 23/04/2013, available from http://europa.eu/rapid/press-release_ SPEECH-13-357_en.htm (retrieved on 28/04/2013).

2 Eurobarometer 71.3 Globalization, Personal Values and Priorities, European Identity, Future of the European Union, Social Problems and Welfare, and European Elections June / July 2009, data available from the following website, http://www.gesis.org/en/eurobarometer/ data-access/, retrieved for the last time on 08/07/2013 
The EU is often said too distant for the general public because of its slow decision making, its distance from national affairs and its lack of personalisation. This has been addressed recently in intellectual debates through the notion that the EU lacks a suggestive narrative, understood as an inability to select, articulate and communicate EU policies via a convincing public discourse on its positive effect on the lives of Europeans ${ }^{3}$. This «narrative turn» encompasses previous reflections on the EU democratic deficit, identity issues and the lack of a European public sphere. However it turns out that in the wake of the financial crisis the EU is becoming an issue of internal politics and has never been so present in the public sphere ${ }^{4}$. Eventually the old permissive consensus on EU issues may be replaced by a «constraining dissensus» ${ }^{5}$ : from a certain point of view it could be argued that the EU actually suffers from a narrative inflation rather than a deficit. Actually EU integration is often justified on the grounds of diverse and sometimes contradictory narratives such as deepening and widening or competitiveness and social security. This article discusses whether the recent narrative turn is compatible with the increasing contention of EU issues and develops a framework for analysing the way in which different narratives of the EU are put forward by political actors.

The aim of this article is not to analyse the possible new and alternative narratives for European integration but rather to understand how narratives are used by political actors - understood as those competing for EU and national offices or influence on the agenda - and whether or not they engage in a debate with each other. In fact the article questions the very notion of political narratives as a re-enactment of the foregone approach to

${ }^{3}$ Examples of this debate are diverse but strongly coincide, providing testimony to the fact that political debates follow generational currents akin to fashion ones. Examples of this is the «Europe ou chaos» debate by the French philosopher Bernard Henri-Lévy and the Franco-German cultural TV channel ARTE. The debate produced a manifesto signed by the following intellectuals and journalists: Umberto Eco, Juan Luis Cebrián, György Konrád, Julia Kristeva, Bernard-Henri Lévy, Peter Schneider, Vassilis Alexakis, Antonio Lobo Antunes, Claudio Magris, Salman Rushdie et Fernando Savater. The manifesto was also simultaneously published in some European media. The manifesto and the January 2013 debate in Paris can be found in the following link: http://www.arte.tv/fr/europe-ou-chaos-une-rencontre-debat-filmee/7275206, CmC=7276002.html (retrieved on 28/04/2013). On the argument of Europe's lack of narrative consistency see SASSATELLI, M., Has Europe lost the plot? Europe's search for a new narrative imagination, European Cultural Foundation, Amsterdam, 2012.

${ }^{4}$ BECK, U., Non à l'Europe allemande. Vers un printemps européen, Autrement, Paris, 2013.

5 HOOGHE, L. and MARKS, G., «A Postfunctionalist Theory of European Integration: From Permissive Consensus to Constraining Dissensus» British Journal of Political Science 39 (01), 2009, pp. 1-23. 
European integration that was characterized by a passive consent of the population towards EU policy-making. Instead, the paper argues that the EU is becoming increasingly politicized and that attempts to establish a new coherent narrative are characteristic of a thin conception of democracy attempting to avoid debates on EU policies and political choices under the aegis of a consensual project. My approach is that it is not possible to re-enact a broad un-political consensus on the EU. Instead the article emphasises the plurality of narratives on the EU and points that the fragmentation of the European public sphere is the more substantial problem for an overarching new narrative. The politicisation of EU policy making together with the Europeanisation of national political debates has a stronger potential to reach the European public.

The first section discusses the notion of political narrative and the limits it is likely to experience at EU level. The second section discusses the way in which the narrative turn is conceived by the Commission and contrasts it with the politicisation of European integration. The third section builds on two examples - with no intention of generalisation - to show that it is not true that discourses on Europe do not exist and points rather to the lack of debate fora.

\section{Narratives in the fragmented European public sphere}

The narrative turn in EU studies is very recent ${ }^{6}$. However it is a direct consequence of the last two decade's debate on the EU public sphere and the EU's reflection on its relation with citizens. The Danish rejection of the Maastricht Treaty - together with the often forgotten very close result in France - were the first indicators that the frequent neglect of EU issues by the public did not imply a form of support. In the wake of the subsequent debate on the democratic deficit, the EU entered into a phase of intense yet paradoxical democratisation of EU policy-making. Every single Treaty in the last two decades - Maastricht, Amsterdam, Nice, the constitutional Treaty and Lisbon - has extended the powers of the European Parliament which, short of turning the EU into a typical parliamentary system, is now the co-legislator in most matters, has a veto power on the designation of the executive and can remove the Commission through a vote of no confidence. Furthermore, the EU has attempted to create democratic opportunities beyond representative democracy by fostering a debate on forms of par-

${ }^{6}$ SASSATELLI, S., op. cit., LACROIX, J. and NICOLAIDIS, K., European Stories. Intellectual Debates on Europe in National Contexts, Oxford, OUP. 2011. 
ticipation by organised civil society ${ }^{7}$. The paradox is that despite this clear, albeit probably insufficient democratisation, European citizens have not responded by endorsing the changes but by growing apathy and distrust.

This paradox suggests that the EU may not exactly or only suffer from a democratic deficit which could be solved via institutional reform but from a deeper problem of democratic legitimacy ${ }^{8}$. In this sense, the EU is not suffering, or not mainly, from a problem of political accountability within the institutions, but rather from a lack of political relevance and visibility for the citizens. The problem of democracy in the EU is not whether its institutions are formally accountable to the people - most of them are accountable to elected bodies and to national or European electorates - but whether there is sufficient political competition and alternatives to make the choices that the EU has in front of itself visible for its' citizens ${ }^{9}$.

The lack of a pan-European public sphere is thus pointed out as the main obstacle for the ability of Europeans to form a political community beyond the nation state. That said, the notion of the public space as «the sphere where private people come together as a public» ${ }^{10}$ is not logically but historically linked to nation states and one can imagine that private people can come together as a multi-national or postnational public not bound to the state but constructed by mutual recognition ${ }^{11}$ via shared narratives. In this sense some historians and sociologists have considered that the notion of the public sphere could be applied to the level of the EU without substantially modifying the focus on the long term emergence of a common European public as historically publics have emerged along spheres of economic exchange and political power ${ }^{12}$.

${ }^{7}$ In a nutshell the decade of the 2000 has been rich in institutional and political discussion on reforming EU institutions, from the famous discourse of Joschka Fischer in Berlin (2000) to the Commission's White Paper on Governance (2001) and the proposal of a European Constitution elaborated by a Convention (2002-2003). The rejection of this text in France and the Netherlands in 2005 opened a period of reflection that ended with the signature of the Lisbon Treaty (2007). The rejection of this Treaty in a referendum in Ireland (2008) delayed its entry into force until late 2009.

8 CHOPIN, T., «Le désarroi Européen.» Commentaire, n. 129, printemps 2010.

9 GOULARD, S. and MONTI, M., De la démocratie en Europe, Flammarion, Paris, 2012.

10 HABERMAS, J., The Structural Transformation of the Public Sphere, Polity Press, Cambridge, 1989. p. 27.

${ }^{11}$ HABERMAS, J., La constelación postnacional, Paidòs. Barcelona, 2000.

12 KAELBLE, H., «The Historical Rise of a European Public Sphere?» Journal of European Integration History 8 (2), 2002, pp. 9-22; DELANTY, G., and RUMFORD, C., Rethinking Europe. Social Theory and the Implications of Europeanization. Routledge, London and New York, 2005. 
In this sense the narrative turn points out that one of the reasons for this lack of relevance of the EU for its citizens is that the EU has not been able to create a message that makes it clear to the people why this project is relevant and necessary today. In this sense it is usual to read that the EU needs to be narrated or «re-emplotted» in order to make sense to the citizens and to show them that it is more than a technocratic project but that there is a more profound sense and a soul behind the project ${ }^{13}$. This narrative turn is of course not exclusive of EU politics. It is generally pointed out that the global crisis is having such a strong impact on national politics because political leaders and actors are not able to create a convincing narrative on its origin, effects and ways to overturn it.

That said the notion of narrative - as previously that of discourse - is used without making it explicit what it is meant by it. It is possible to start from the following approach by Sandra Sassatelli: «As narrative analysis insists, stories are complex artefacts. It is useful to distinguish at least three components: an appropriately selective series of past events and forces, a temporal sequence and, more importantly, an "emplotment" that establishes causal links and communicates, possibly, moral lessons.» ${ }^{14}$ In this sense a political narrative is an articulated selection of political events organised in a temporal sequence with the intention of communicating a political message. In this sense it is obvious that the narrative turn is about the way in which EU institutions and political actors choose different elements of European integration to build an argument about it in order to derive a message. In this sense narratives can have diverse aims and goals, either to justify or to criticise European integration. But in both cases the basis of any narrative is a selective usage of events and a particular form of establishing links between them.

The question that needs to be raised is of course what is the relation between political narratives and political reality, if for a moment we can assume that we apprehend political realities by other means than narratives. Shaul Shenhav sees this relation within two opposed poles, one where there is no assumption that the narrative can have an ability to represent reality and one where it is assume to fully do so ${ }^{15}$. Intermediate positions are those where narratives can have episodical or chronological ability to represent reality. Furthermore, Shenhav points out that narratives themselves contribute to construct political reality. In this point we can follow new institution-

13 BARROSO, J.M., op. cit, footnote 1.

14 SASSATELLI, S., op. cit., p. 2.

15 SHENHAV, S.R., «Political Narratives and Political Reality», International Political Science Review, 27: 3, 2006, pp. 245-262. p 251. 
alists in their recent turn towards «taking ideas and discourses seriously» ${ }^{16}$. Although discursive institutionalism does not use the notion of «narrative», it is useful to consider the role of discourse in a broad sense in the construction and reproduction of political institutions. One of the clearest ways in which neo-institutionalists have addressed the issue of the role of discourse in the transformation of institutions is via the notion of frames and framing. Discursive new institutionalists have found that the way in which political actors represent political reality evolves according to the policy-field where they $\operatorname{are}^{17}$. There is a certain logic of appropriateness and need of coherence within a given field which establishes limits to the freedom that actors have to change their narratives. Similarly, studies of how frames circulate from one field to another and in particular how political actors seek to amplify their frames from elite fields to the general public ${ }^{18}$ are also of great importance in the context of narratives on European integration because of the fragmented nature of its public sphere ${ }^{19}$.

In this sense attempts to build narratives of European integration that can be shared by the general public across Europe are likely to fail because of the weak connection between the spheres of narrative production and the public. The EU shares this fragmentation with most modern public spheres, but it suffers from a specific disconnection between institutional, specialised and segmented publics ${ }^{20}$. What is missing is the link between policy discussion, political competition and the sphere of media communication.

However this does not mean that narratives of European do not exist in general publics. On the contrary, Schlesinger and Deirdre ${ }^{21}$ suggest that a quest for a unified European public and common narratives conduces to determinism about the inexistence of a European public sphere. Thus most authors foresee the constitution of publics alongside the institutions and

16 SCHMIDT, V., «Taking ideas and discourse seriously: explaining change through discursive institutionalism as the fourth "new institutionalism"» European Political Science Review, n. ${ }^{\circ}$ 2, vol. 1, 2010, pp. 1-25.

17 SCOTT, R., Institutions and Organizations. Ideas and Interests. 3rd ed. Sage Publications. Thousand Oaks, 2008, pp. 185-190.

${ }^{18}$ MULLER, P., «Esquisse d'une théorie du changement dans l'action publique.» Revue Française de Science Politique 55 (1), 2005. pp. 155-187.

19 ERIKSEN, E. O., «Conceptualising European Public Spheres. General, Segmented and Strong Publics» in FOSSUM, J. E., and SCHLESINGER, P. (eds), The European Union and the Public Sphere. A Communicative Space in the Making?, Routledge, London.

${ }^{20}$ Ibid.

${ }^{21}$ SCHLESINGER, P. \& DEIRDRE, K., «Can the European Union become a public sphere of politics?» in ERIKSEN E.O. \& FOSSUM, J.E. (eds.), Democracy in the European Union: integration through deliberation?, Routledge, London, New York, 2000, pp. 206-229. pp. 220-221. 
policies of the European Union rather than the emergence of a general European public. However contrary to what EU institutions may expect an increased debate on the European Union may be the result of the mobilization of actors EU are not necessarily supportive of the current consensus. In this sense this article argues that the emerging politicization of European integration is producing a set of competing narratives that may have a more significant potential of legitimization for EU integration than a univocal official narrative.

\section{European narratives and politics: consensus versus competition?}

This approach is thus useful to analyse whether narratives of European integration can resonate «top down» in a context of increased politicisation. In this sense it is first necessary to analyse the way in which the president of the European Commission understands the need to produce a new narrative of European integration.

The speech by President Barroso as well as the manifesto of European intellectuals mentioned above emphasise the generational dimension of the narrative break in European integration. Younger European generations have not known war but are suffering from another generational trauma, mass unemployment and a lack of trust in the future under the idea that they will be worse off than their parents' generation. In this sense the intention seems to be to create a new narrative that can foster consensus on the EU as the previous one did. As earlier generations had the narrative of not repeating the war, a new narrative of prosperity and union has to be created for today's Europeans.

However it is highly questionable that the narrative of peace, integration and reconciliation was actually the reason why Europeans consented to EU integration. The literature points since the 70s that the EU was characterised by a «permissive consensus» ${ }^{22}$ whereby EU policies were led by political and technocratic elites with a benign neglect by public opinion which ignored the process did not object to their results because those were limited to low politics and were difficult to object to . It rather seems that EU integration has happened thanks to the un-involvement of public opinion rather than because of a general consensus. Obviously this lack of interest in EU matters was made possible because it was seen as generally positive. However, this is not the same to admit that public opinion was supportive of the

${ }^{22}$ LINDBERG, L. and SCHEINGOLD, S., Europe's Would Be Polity, Prentice Hall, Englewood Cliffs, 1970. 
EU in the past. The lack of interest of public opinion for the EU has only been seen as problem since the growth of Euroscepticism in the late 90s.

The question today is whether the EU has already gone beyond the old permissive consensus and whether it has been replaced by a new context of increased political competition. The short answer seems to be yes for the first question but no for the second one. It is clear that the EU can no longer build on the benign neglect from public opinion. The alternatives seem to be the construction of a new consensus away from public opinion or the politicisation of alternatives on the EU, understood as an «increase in polarization of opinions, interests or values and the extent to which they are publicly advanced towards policy formulation within the $\mathrm{EU} »^{23}$.

The usage of narratives is very different in both scenarii. On the one hand the alternative of the Barroso Commission seems to be to try to build a new all-encompassing narrative to reduce dissensus. The first option dominates political and institutional discourse on political union. Such union is often formulated as an overarching institutional redesign whereby supervision mechanisms will be reinforced as to be able to influence and modify national economic policies. It is implicit that this will be democratically supervised, although the impression is that the rules will leave little margin of manoeuvre 24 . In this sense it is akin to what Pierre Rosanvallon calls an «unpolitical democracy», whereby the aim of governance is to maintain a given consensus rather than to facilitate a democratic competition between alternative projects ${ }^{25}$. The recent speech by president Barroso can be quoted at length to make this point clear:

«At a time when so many Europeans are faced with unemployment, uncertainty and in many cases growing inequality, the reality is that a sort of "European fatigue" has set in, coupled with a lack of understanding. Who does what, who decides what, who controls whom and what? And where are we heading to? Anxiety questions. These are all questions that demand a clear answer. To be fair, they are not only European. Many of them, we see them also posed in other parts of the world where we see also some populist extremist trends coming up and I don't mean only the fundamentalist threats, but I mean also events in industrial societies like

${ }^{23}$ DE WILDE, P., «No Polity for Old Politics? A Framework for Analyzing the Politicization of European Integration», Journal of European Integration, no. 33 (september), 2011, p. 559.

${ }^{24}$ See the first « German » scenario of strong integration with small margin of policy choices in DULLIEN, S. and TORREBLANCA, I., «What is political Union», Policy Brief of the European Council on Foreign Relations, http://ecfr.eu/page/ECFR70_POLITICAL_ UNION_BRIEF_AW.pdf, December 2012.

25 ROSANVALLON, P., La contre-démocratie, Seuil, Paris, 2006, p. 260. 
the United States, where we see also this kind of populism coming up. It is linked to the anxiety that arrived from change that is very fast and by globalisation trends. So, we need to have answers, because I also believe that we cannot have more sustainable European integration without more European democracy and we cannot have a more effective Europe without more European legitimacy.

The truth is that Europe is a daily reality for more than 500 million Europeans and yet the public opinion is fragmented mainly along national borders. This is the reality.» 26

This project is thus characteristic of a consensual and elite driven conception of European integration. Firstly, distrust or lack of interest is necessarily associated with lack of information or in this case, with an inadequate narrative. The text quoted above mentions «a lack of understanding» and the fact that public opinion is not Europeanised as factors explaining lack of support for EU integration. The assumption seems to be that if only citizens knew the things the EU does for them they would support the project. Secondly, demands for stronger accountability of the EU in relation to the management of the economic crisis in the form of questions «Who does what, who decides what, who controls whom and what? And where are we heading to?» are associated with populism and scepticism on the European project. The intention of the new narrative project is thus to recreate consensus on the EU rather than foster a debate on EU integration or to facilitate the accountability of EU institutions to citizens.

This is why this way of approaching narratives of Europe is characterised by a relatively weak democratic conception. It sees EU integration as a project driven by elite consensus producing public goods that are beneficial for all Europeans and identifies distrust with lack of understanding or with populism and extremism. This is not to say that any narrative turn in EU integration must be seen on a negative light from a democratic perspective. Firstly, consensus is the basis of any political community. The approach of President Barroso seems to be that consensus about the need of European integration is still too fragile and that any criticism may be prejudicial. However one can ask if precisely the diversity of narratives on EU integration is not indicative of disensus on EU integration but of a pluralistic political system where policies are contested without contesting the polity.

On the other hand it is possible to analyse to what extent the EU already sees the emergence of politicised narratives, understood as an elaborated selection of events and the establishment of causal relations between with the aim of advancing political positions which are promoted by differ-

${ }^{26}$ BARROSO, J.M., op. cit. footnote 1. p. 3. 
ent political forces to different aims. On the contrary, it can be argued that the indifference of public opinion towards the EU is rooted precisely in the perception of a consensual political field where participation does not really matter. The structural fragmentation of the European public sphere makes pan-European competition of different narratives more difficult. In this sense it is unlikely that a bipolar political competition between well defined forces on a small number of cleavages may emerge. However this is not in itself an obstacle to politicisation: whereas the EU may not be about to engage in a clear bipolar politicisation, Papadopoulos and Magnette contend with Hix that the EU can become more politicized without losing some of its consociational characteristics ${ }^{27}$. One of the main tools of a form of politicization along consociational lines would be an increased usage of participation mechanisms to channel conflict over specific policies, as it happens in Switzerland ${ }^{28}$. Furthermore, this strategy can also benefit from the increased usage of participatory innovations to try to rebuild participation and accountability links back with the public ${ }^{29}$ which the EU has already developed in the last decade. Democratic innovations defined as purposefully designed mechanisms for improving the quality of democracy through greater citizen participation ${ }^{30}$ is a very active research field and one where the EU has developed mechanisms for interaction with civil society organisations and to promote transparency.

\section{How do stories circulate in the fragmented European public sphere?}

The EU has been characterised by the growth in the diversity of narratives since the beginning of the integration project. Some of the traditional oppositions are intergovernmental versus supranational Europe, the political or federal project versus the economic one, the opposition between a vision for a social Europe versus free trade or ideas of common values and identity on the ground of common heritage versus national identities. Nevertheless if these ideas have strongly resonated in debates on European in-

27 PAPAdopoulos, Y. and MAGNETTE, P., «On the Politicisation of the European Union: Lessons from Consociational National Polities», West European Politics, 33 (4), 2010, pp. 711-729.

28 Ibid.

29 SMITH, G., Democratic Innovations, Cambridge University Press, Cambridge, 2009.

30 GEISSEL, B., «Impact of democratic innovations in Europe. Findings and desiderata» In GEISSEL, B. and NEWTON, K. (eds.), Evaluating Democratic Innovations: Curing the Democratic Malaise?, Routledge, New York, 2012, p. 164. 
tegration $^{31}$ they have rarely structured political competition at EU or member state level, with rare exceptions such as the debate on Christianity in the EU constitution ${ }^{32}$, on the eventual access of Turkey to the EU or on the economic liberalism of the EU. This section takes the form of recent examples of how some of these narratives are now circulating on the public sphere: debates on the accession of Turkey to the EU and of the governance of the Euro. These are used to show that there are very visible and differentiated narratives on these important domains, although it also appears that narratives do not always engage with each other in a debate on the future of the EU. In this sense it is possible to ask whether what is missing at EU level is the plot or rather the other elements of a narrative, the narrators and the audience.

\section{Deepening versus widening: the contentious case of Turkey}

Although the position of political leaders in relation to Turkey is usually linked to the debate on migration at the national level ${ }^{33}$, there are no «natural reasons» why this country's application should have become contentious. In particular it is interesting to consider how positions on the enlargement to Turkey are telling about larger views of the EU and are related to particular narratives of European integration. The position of political leaders on Turkey's accession can be closely related to their position on the EU political field ${ }^{34}$. Thus, discourses about Turkey must be analysed in relation to the actors' broader narrative on EU integration and not only in relation to an ideological perspective on Islam or on domestic debates ${ }^{35}$. In this sense, the way in which national leaders frame the accession of Turkey to the EU is telling firstly about their narratives on the nature of the EU and secondly of their position in the EU's power field.

31 See among many others the reflection of these tensions in DELANTY and RUMFORD, op. cit.

32 AIRIAU, P., «Disputatio Dei', L'action politique des catholiques Français partisans de 'l'héritage Chrétien.» in COHEN, ANTONIN and VAUCHEZ (eds.), La Constitution européenne. Elites, mobilisations et votes, Editions de l'Université de Bruxelles, Bruxelles, 2007.

${ }^{33}$ LAGRO, E., and JØRGENSEN, K.E., (eds) Turkey and the European Union. Prospects for a Difficult Encounter, Palgrave Macmillan, Basingstoke, 2007.

${ }^{34}$ BOUZA GARCÍA, L., «European political elites' discourses on the accession of Turkey to the EU: discussing Europe through Turkish spectacles?» in European Perspectives of the Western Balkans, vol. 3 (2) 2011.

35 TEKIN, B.Ç., «The construction of Turkey's possible EU membership in French political discourse», in Discourse \& Society, vol. 19(6), 2008, pp. 727-763. 
Starting with sceptical views, former French president Sarkozy's position, one of the most critical opponents of Turkey's accession, must be understood within a wider political or geopolitical narrative, in the first case on a project for the future of the Mediterranean and in the second on the vision of Europe. Whereas Sarkozy's statements on Turkey were usually appraised from the cultural perspective, it may be more appropriate to approach these within the context of a narrative on the EU and his own position in the EU political field.

Turkey features in Sarkozy's discourse within a larger context. Turkey's application is framed as part of an Anglo-Saxon strategy seeking to weaken the political coherence of the EU via an increase in diversity which would make governance even more difficult. Moreover, the rejection of Turkey's application is framed with the same justification provided for the French ratification of the Lisbon Treaty: strengthen Europe's will, that is, govern, steer and foster its unity. Consequently, Turkey is associated with Europe losing control over itself and its application is rejected for the sake of a stronger European unity. This view is synthetically but clearly stated in his speech in Toulon, still as candidate to France's presidency:

«Europe cannot extend itself endlessly. If Europe wants to have an identity, it must have borders and thus limits. If Europe wants to have power it must stop diluting itself endlessly. If Europe wants to be able to operate it cannot enlarge without stop.» ${ }^{36}$

The association of Turkey, power and governance is also useful to frame a geopolitical approach in a more acceptable way. Because of its size Turkey would become one of the largest players in the Council, thus diminishing the relative share of power of France. Turkey is thus the eponym of narratives equating further enlargement with a dilution of European integration ${ }^{37}$. Even though Nicolas Sarkozy has now quitted France's presidency, his arguments remain relevant as an example of a narrative demanding the definition of the borders of the EU because of power balance and identity reasons. It is argued that in order to proceed with further integration it is necessary to avoid increasing diversity in terms of interests and culture in the EU. Although further enlargement is not considered impossible, this narrative sees the current borders of the EU as more or less definitive and only envisages the possibility of admitting the relatively small states

36 SARKOZY, N., «Discours de Nicolas Sarkozy», 07/02/2007, available from the following website: http://sites.univ-provence.fr/ veronis/Discours2007/transcript. php?n=Sarkozy\&p=2007-02-07 retrieved on 02/05/201, translated from French by the autor.

37 GOULARD, S., Le Grand Turc et la République de Venise, Fayard, Paris, 2004. 
of the Western Balkans or the uncontroversial members of the European Economic space. The position of Angela Merkel is similar to Sarkozy's, that Turkey should aim for a special partnership but no full EU membership. The fact that Germany has not blocked accession - letting negotiations go on until an eventual accession - has to do the consensus policy adopted under the Grand Coalition which ruled Germany in the early 2000s and the Chancellor respecting it on the name of the principle «pacta sunt servanda» ${ }^{38}$.

On the other hand, the opposite narrative portray enlargement as a way to strengthen European integration, in particular in relation to the internal market and its claim to be a world power. Former Spanish President José Luis Rodríguez Zapatero for instance argued that his position in favour of Turkey joining the EU is related to his pro-European attitude and his concern for the stability of the Mediterranean and the role of the EU in the world. Undoubtedly it has as well a geopolitical intention to compensate the enlargement towards central Europe with a move towards the Mediterranean. This is confirmed by the fact that the current Spanish government shares this position.

«Turkey is a country of strategic importance for Spain in our relations, not only because of the friendship that unites us, but because of our shared interests. We are Mediterranean countries, sensitive to the stability and prosperity of this region and to the promotion of the peace process in the Middle East. Spain finds in Turkey a regional actor of prime importance and appreciates its contribution to regional initiatives.» ${ }^{39}$

Again these arguments remain relevant despite the fact that Zapatero is no longer Head of Government because it remains the position of the current Spanish Government and it is telling about a specific narrative of European integration.

This example contributes to show that narratives of European integration do exist and are politically cleaved. Furthermore, they confirm the importance of narratives in political competition at EU level. The analysis of these narratives does not imply that discourses on enlargement and accession are not addressed to national public opinions. However it must be em-

38 European Stability Initiative, «The German Turkey Debate under the Grand Coalition: State of the debate», October 2006, available at: http://www.esiweb.org/pdf/esi_turkey_ germany_grand_coalition.pdf

39 RODRÍGUEZ ZAPATERO, J.L., «Intervención del presidente del Gobierno en la cena de celebración del fin del ayuno diario del Ramadán», 15/09/2009 available from (consulted last on 27/10/2009): http://www.la-moncloa.es/NR/exeres/6760064B-326C-43A8-A66CEE7E4BBB5F3F,frameless.htm?NRMODE=Published 
phasised that these narratives are not only addressed to national publics but that they are a sign of political competition at EU level between anti and pro accession leaders as the narratives speak to each other and arguments are adapted to those of the contrary positions. In this sense arguments about Turkey's accession to the EU are used as part of a wider narrative on European integration.

The excerpts discussed above provide examples of the «importance of ideas and discourse» as discussed by the new stream of institutionalism quoted above. Even though the position on Turkey is not formed on the basis of a left / right opposition at the EU level but rather on geopolitical visions of member states in the EU, they show that arguments and positions are framed by political actors in a broader perspective of EU integration and influenced by a logic of appropriateness. They thus contribute to build narratives on European integration in relation to the connection between enlargement and deepening and thus to start a conversation facilitating that national publics visualise the cleavages in relation to this policy In this way they contribute to the Europeanisation of national publics in the absence of a pan-European public space.

\section{Narratives of economic integration: the contentious governance of the Euro-zone}

The economy has been the central aspect of the EU's strategy to promote peace in the continent. Economic integration remains the driving force of the European project as it has been confirmed by the recent euro-crisis, which has increased the attention for EU in all members of the euro-area, further contributing to the politicization of the EU.

If the method of economic integration has been consensual in the past, this does not mean however that the EU has been characterised by a single narrative in the economic sphere. In this sense the early years of EU integration were characterised by a strong tension between free trade and more statist visions that were critically epitomised in the negotiations on the EEC common tariff and France's rejection of the UK's application. The late 80s and 90s saw a strong debate between social and liberal Europe that gave rise to the European social dialogue. In recent years there had been a convergence of social and liberal discourses on the EU economy in the wake of the «third way» left policies. The best example of such convergence was the Lisbon agenda strategy. But again, these narratives rarely had an effect on structuring discourse and political competition beyond Brussels.

However the management of the euro-crisis has exacerbated the cleavage between social and liberal discourses, in particular the tensions between 
austerity and competitiveness against growth and solidarityIn this sense the EU's response to the economic crisis started in 2008 was to reduce public deficit with two main arguments: to direct scarce credit towards the private sector and to reduce fears that the euro may break up as a result of the different fiscal situation of the members of the euro-area. This was a coherent economic policy inspired in liberal paradigms considering the public sector an inefficient burden for economic competitiveness and fiscal transfers in the name of solidarity between members of the eurozone as a form of moral hazard. Furthermore this policy was adopted at a moment when centre to right political actors had a very strong majority in the Member States, the Commission and the European Parliament. This means that for the first time in the history of the EU policies are not the result of a compromise between different views but driven by a clear paradigm. Even though the policy was adopted by the then socialist governments of Portugal, Spain and Greece, this was the result of the need of these governments' support from other eurozone members and their isolation.

That said this does not mean that centre-to-left forces have come to accept the merits of austerity and of lack of transfers between members of the euro-area. Although these forces are clearly in minority among the governments of the euro-area, the election of a socialist government in France in 2012 and the negative consequences of fiscal consolidation for economic growth and employment have resulted in a growing discussion of these policies. The current debate shows the cleavages among different political narratives on the economy of the EU. In this sense, the current debate seems to oppose a «German Europe ${ }^{40}$, obviously headed by Chancellor Merkel and supported by the European Commission and other North European countries such as the Netherlands or Finland, to the socialist president of France, supported by the party of European socialists ${ }^{41}$ and social forces such as trade unions. It could be argued that for instance the current conservative Spanish government opposes the arguments of German Europe. Although this scheme is oversimplified, it can be argued that the Spanish government disagrees on grounds of national interests albeit sharing the discourse on the merits of austerity.

Most mainstream political forces in the EU agree that the governance of the euro requires a stronger coordination and integration of fiscal policies in the EU. Nevertheless the approaches are quite different in terms of

40 BECK, ibid.

41 Party of European Socialists «PES proposes clear crisis measures before treaty change» (08/12/2011), http://www.pes.eu/en/news/pes-proposes-clear-crisis-measures-treatychange 
the preferred rhythms and outcomes ${ }^{42}$. On the one hand, proponents of austerity argue that any common fiscal policy can only be adopted after the increased control of national budgets by EU institutions and once member states have overcome their huge disparities in terms of economic structure and competitiveness. This is in order to avoid that the countries with sound economic governance and more competitiveness would be undermined by the others. In this sense, any measures aiming at a greater integration of fiscal policies - via tax harmonization or Eurobonds - can only be considered on the longer run. On the other hand, those critical with current governance schemes point out that stronger fiscal integration is necessary as a first step in order to foster greater solidarity between those countries suffering from assymetrical shocks and those in a better economic situation. The argument emphasises that these resources could be use to foster economic growth policies.

Furthermore, it must be said that these positions are not entirely new, but rather the expression of a relatively old cleavage between discourses on competitiveness and solidarity. This tension has been going on since the early 90s when the Delors Commission proposed social cohesion policies and encouraged the European social partners to start developing a European framework for labour relations. Although as it was said the Lisbon strategy tried to combine social protection and competitiveness, it seems that it was only the economic growth of the 2000 years that favoured that convergence. As soon as the crisis has struck, these alternative narratives have reemerged. So other than on the question of the rhythm of fiscal integration, left and right narratives are also clearly distinguishable on the competitiveness versus solidarity axis.

On the one hand there is a narrative which portrays member states of the EU as competitors in an open economic system. The EU as a whole has to compete at world level with other global economic actors. In this sense every country in the EU must ensure that it is able to compete internally and globally, and otherwise reform its economy. Whereas this was traditionally checked for candidates to join the EU via the economic dimension of the Copenhagen criteria - candidates must be able to compete in the internal market - this narrative is now strongly enforceable internally. As a result of the euro-crisis, the EU has developed a whole legislative strategy aiming to an external control of both member states fiscal policies and internal macro-economic imbalances, the so called «two pack» and «six-pack»

42 See TORREBLANCA and DULLIEN (op. cit.) for a full discussion of the different degrees of fiscal policy integration in different scenarios of further political integration Europe. 
regulations ${ }^{43}$. These control mechanisms have been criticized $^{44}$ by pointing out that they reduce the margin of manoeuvre of policy-makers and do only allow for economically liberal policies emphasizing external competitiveness ${ }^{45}$.

The competitiveness narrative does not completely sideline solidarity. In fact it emphasizes that the new bailout mechanisms are an expression of solidarity between members of the Euro-area. But in this narrative solidarity is linked to responsibility: since countries have irresponsibly managed their fiscal policies, higher control will be exerted in exchange of solidarity ${ }^{46}$. Austerity for bailed out countries is both the necessary counter dimension of EU solidarity and a self-help mechanism aimed at producing internal devaluation and thus make the country more competitive.

On the other hand proponents of a social Europe tend to point out that the economic integration of the continent requires a transfer of solidarity mechanisms from the nation state to the EU level, lest European competition produce a race to the bottom of social protection standards as a result of social dumping. The narrative argues that in order to avoid this, European solidarity mechanisms have to designed, in particular aiming at taxing movements of capital across Europe, establishing minimum salaries and unemployment benefits at European level and enhancing the approximation of national legislations on social security.

This narrative is critical of recent evolutions of the EU in the field of social governance, considering that even before the current crisis the EU had abandoned its social agenda in favour of ideas of competitiveness. In this sense, it is argued that social cohesion policies have remained weak and that the social security and work regulation legislation has advanced little in recent years. The enlargement towards central Europe and the increased spread of neo-liberal agendas and forces is usually blamed for this

43 CERCAS, A., «Las implicaciones políticas e institucionales de la nueva gobernanza europea», in Gaceta Sindical, number 18, June 2012.

${ }_{44}$ CLOSA, C., «El nuevo «compacto fiscal» de la UE: constitucionalismo y democracia», paper presented at the International Conference on Spain and European Integration, organised by the Fundación Academia Europea de Yuste and the Centre pour a Connaissance de 1'Europe, 16-17 april 2012, Yuste, Spain.

45 On the role of EU economic governance in embedding neo-liberal policies in national constitutions see BRADANINI, D., «The Rise of the Competitiveness Discourse: A Neo-Gramscian Analysis» in Bruges Political Research Papers, number 10, 2009. Available online at: http://www.coleurope.eu/fr/website/etudier/etudes-politiques-et-administrativeseuropeennes/activites-de-recherche/cahiers-de (retrieved on 30.04.2013)

46 On the conception of solidarity behind the bail-out mechanisms see FERNANDES, S., and RUBIO, E., «Solidarity within the Eurozone: how much, what for, for how long?», Notre Europe , 2012 http://www.eng.notre-europe.eu/media/SolidarityEMU_S.Fernandes-E.Rubio_NE_Feb2012.pdf 
evolution. This narrative is logically critical of the current governance of the euro-crisis. It points out that not only that austerity and competitiveness have negative social consequences but have not been able to stabilize the budgets of member states and that have deepened the recession in the euroarea. This does not mean that the solidarity narrative sees no need to stabilize public budgets, but it considers that this should not be done in a competitive way. In this sense, those countries which are doing better should accept to lose some competitiveness and increase their spending in order to favour those more affected to escape recession sooner.

As the abovementioned narratives on enlargement, the narratives on economy and growth in the EU are also strongly influenced by the national belonging of the narrators. In this sense even though centre-to-right forces in Southern European countries share the view of the need to contain public spending to regain competitiveness, they clearly disagree on the rhythm and the intensity of the fiscal integration. Nevertheless because of the relevance of this agenda the EU is probably witnessing one of its first pan-European discussions on a clear narrative, that of austerity against growth and the need of sovereignty transfers or not. Even though the debate remains closely linked to national interests there is a clear understanding among public opinions that decisions on national economic policies are increasingly influenced by EU level decisions and can eventually come to see their preferences and interests represented by another political party or leader than those in their own country.

\section{Conclusion}

This article has quickly reviewed a very recent turn of the EU's towards the search of a new narrative. It has built on the argument that there is no evidence to say that Europe has moved away from a narrative on the need of EU integration to overcome war in the sense that up to now European public opinion has not been shaped by an overarching narrative but rather by a passive permissive consensus.

The discussion of the usage of the new narrative in the speech of the Commission's president and the review of two examples in the field of enlargement and economic governance provides ground for the need of further research on the narrative turn. Firstly the article shows that there is little ground to say that European integration is lacking a narrative. In this sense, it has found that the politicization of European integration, understood in de Wilde's sense as a polarisation of opinions that are publicly advanced towards policy-making in the EU, is contributing to the emergence of different narratives that are advanced by different political actors and 
forces. In this sense it appears that rather than a deficit there are a relatively important number of narratives.

Secondly the article has found that there are at least two different possible approaches in relation to the politicisation of narratives of European integration. On the one hand, the Commission and European intellectuals are promoting a narrative aimed at fostering a stronger sense of belonging to a European political community in particular among younger generations. It is a narrative that emphasizes the existence of a common European culture and historical achievements and the need to strengthen European integration to sustain democracy and social welfare in a globalizing world. However this narrative is characterized by an elitist approach to dissensus and the idea that disagreement is rooted in lack of understanding or knowledge, for which there is no clear evidence. On the other hand, the article has pointed out that a number of politically differentiated narratives are emerging on some of the more salient aspects of European integration, such as enlargement or the economy. These narratives emphasise different aspects of EU integration and articulate different points of view, which means that they can articulate political competition at European level express their preferences. So whereas an overarching narrative us unlikely to reach the general public because of the fragmentation of the public sphere, politicised narratives on the EU can rely on existing «narrative structures» - political parties, media and social movements - at national and European level.

Thirdly the article also finds that the existence of narratives does not necessarily mean an increased mutual awareness and pan-European debates and political competition. As Sassatelli asks «Is [Europe] lacking in emplotted stories or - equally importantly, [...] dedicated storytellers and public spheres? ${ }^{47}$ First of all decision making at EU level will remain characterized by a high level of consensus for a long time ${ }^{48}$. Because political competition has been found as to be the main catalyst for narratives of European integration, a relatively weak competition will mean that the emergence of new narratives will be small. And secondly the articulation of the narrative is different in every field. Whereas the article finds a clearly distinguishable left / right polarization in the economic field, narratives on EU enlargement can be explained according to different inter-governmental and geo-political perspectives. Nevertheless, it has also been found that even in the latter case political actors use narrative strategies and that their framing is constrained by a logic of appropriateness whereby they need to justify their position according to the stakes of EU integration and not only on the grounds of national interests.

\footnotetext{
${ }^{47}$ SASSATELLI, S., op. cit. p. 2.

48 DE WILDE, op. cit.
} 
The article concludes that an all-encompassing narrative decreasing the contentiousness of EU integration is unlikely to succeed because of the structural division of the public sphere and the increasing politicisation of EU integration. Nevertheless these two factors will enhance the emergence of competing narratives promoted by different political actors to build their position on the EU political field although these narratives will often ignore each other. This article has established an analytical framework which calls for further research putting emphasis on the analysis of the construction of the narratives via frame analysis and of their use by political actors via a study of frame mobilisation in different policy fields.

\section{References}

AIRIAU, P., «Disputatio Dei', L'action politique des catholiques Français partisans de 'l'héritage Chrétien.» in Cohen, A. and Vauchez, A. (eds.), La Constitution européenne. Elites, mobilisations et votes, Editions de l'Université de Bruxelles, Bruxelles, 2007.

BARroso, J.M., «A new narrative for Europe» SPEECH/13/357, Palais des Beaux Arts, Brussels, 23/04/2013 available from http://europa.eu/rapid/press-release SPEECH-13-357_en.htm (retrieved on 28/04/2013).

BECK, U., Non à l'Europe allemande. Vers un printemps européen, Paris, Autrement, 2013.

BouZA GARCÍA, L., «European political elites' discourses on the accession of Turkey to the EU: discussing Europe through Turkish spectacles?», in European Perspectives of the Western Balkans, vol. 3 (2), 2011.

Bradanini, D., «The Rise of the Competitiveness Discourse: A Neo-Gramscian Analysis», in Bruges Political Research Papers, number 10, 2009. Available online at: http://www.coleurope.eu/fr/website/etudier/etudes-politiques-etadministratives-europeennes/activites-de-recherche/cahiers-de (retrieved on 30.04.2013).

CERCAS, A., «Las implicaciones políticas e institucionales de la nueva gobernanza europea», in Gaceta Sindical, n. ${ }^{\circ}$ 18, june 2012.

Chopin, T., «Le désarroi Européen.» Commentaire, n. 129, printemps 2010.

CORDUWENER, P., «The relationship between populism and liberal democracy: three new insights», University Association for Contemporary European Studies 42nd Annual Conference, Passau, 2012.

Closa, C., «El nuevo "compacto fiscal" de la UE: constitucionalismo y democracia», paper presented at the International Conference on Spain and European Integration, organised by the Fundación Academia Europea de Yuste and the Centre pour a Connaissance de l'Europe, 16-17 april 2012, Yuste, Spain.

Delanty, G. and Rumford, C., Rethinking Europe. Social Theory and the Implications of Europeanization, London and New York, Routledge, 2005. 
Dullien, S. and Torreblanca, I., «What is political Union», Policy Brief of the European Council on Foreign Relations, http://ecfr.eu/page/ECFR70_POLITICAL _UNION_BRIEF_AW.pdf, December 2012.

Eriksen, E.O., «Conceptualising European Public Spheres. General, Segmented and Strong Publics» in Fossum, J. E., and Schlesinger, P., (eds). The European Union and the Public Sphere. A Communicative Space in the Making?, Routledge, London, 2007.

European Stability Initiative, «The German Turkey Debate under the Grand Coalition: State of the debate», october 2006, available at: http://www.esiweb.org/ pdf/esi_turkey_germany_grand_coalition.pdf

Fernandes, S. and Rubio, E., «Solidarity within the Eurozone: how much, what for, for how long?», Notre Europe, 2012, http://www.eng.notre-europe.eu/media/ SolidarityEMU_S.Fernandes-E.Rubio_NE_Feb2012.pdf

GeIsSEL, B., «Impact of democratic innovations in Europe. Findings and desiderata», in GeISsel, B. and Newton, K. (eds.), Evaluating Democratic Innovations: Curing the Democratic Malaise?, Routledge, New York, 2012, pp. 163 183.

Goulard, S., Le Grand Turc et la République de Venise, Fayard, Paris, 2004.

Goulard, S. and Monti, M., De la démocratie en Europe, Flammarion, Paris, 2012.

HABERmas, J., La constelación postnacional, Paidòs, Barcelona, 2000.

Habermas, J., The Structural Transformation of the Public Sphere, Polity Press Cambridge, 1989.

Hooghe, L. and MARKs, G., «A Postfunctionalist Theory of European Integration: From Permissive Consensus to Constraining Dissensus», British Journal of Political Science 39 (01), 2009, pp. 1-23.

HENRI-LÉvy, B. et al., «Europe ou chaos» http://www.arte.tv/fr/europe-ou-chaosune-rencontre-debat-filmee/7275206, $\mathrm{CmC}=7276002 . \mathrm{html}$ (retrieved on 28/04/2013).

KAELble, H., «The Historical Rise of a European Public Sphere?», Journal of European Integration History 8 (2), 2002, pp. 9-22.

Lacroix, J. and Nicolaidis, K., European Stories. Intellectual Debates on Europe in National Contexts, Oxford, OUP. 2011.

Lagro, E. and Jørgensen, K.E. (eds.), Turkey and the European Union. Prospects for a Difficult Encounter, Palgrave Macmillan, Basingstoke, 2007.

Lindberg, L. and Scheingold, S., Europe's Would Be Polity, Prentice Hall, Englewood Cliffs, 1970.

Muller, P., «Esquisse d'une théorie du changement dans l'action publique», Revue Française de Science Politique, 55 (1), 2005, pp. 155-187.

Papadopoulos, Y. and Magnette, P., «On the Politicisation of the European Union: Lessons from Consociational National Polities», West European Politics 33 (4), 2010, pp. 711-729.

PARTY OF EUROPEAN SOCIALISTS, «PES proposes clear crisis measures before treaty change» 08/12/2011 http://www.pes.eu/en/news/pes-proposes-clear-crisis-measures-treaty-change 
SARKOZY, N., «Discours de Nicolas Sarkozy», 07/02/2007, available from the following website: www.sarkozy.fr/download/? mode=press\&filename $=7$ fevrier2007_Toulon_DiscoursNS.pdf

RODRÍGUEZ ZAPATERO, J.L., «Intervención del presidente del Gobierno en la cena de celebración del fin del ayuno diario del Ramadán», 15/09/2009, available from (consulted last on 27/10/2009): http://www.la-moncloa.es/NR/exeres/6760064B326C-43A8-A66C-EE7E4BBB5F3F,frameless.htm?NRMODE=Published

SAssatelli, M., «Has Europe lost the plot? Europe's search for a new narrative imagination», European Cultural Foundation, Amsterdam, 2012.

Schlesinger, P. \& DeIRdRE, K., «Can the European Union become a public sphere of politics?», in ERIKSEN, E.O. \& Fossum, J.E. (eds.), Democracy in the European Union: integration through deliberation?, Routledge, London-New York, 2000, pp. 206-229.

SCHMIDT, V., «Taking ideas and discourse seriously: explaining change through discursive institutionalism as the fourth "new institutionalism"», European Political Science Review, 2(1), 2010, pp. 1-25.

ScotT, R., Institutions and Organizations. Ideas and Interests. 3rd ed. Thousand Sage Publications, Oaks, 2008.

Shenhav, S.R., «Political Narratives and Political Reality», International Political Science Review, 27: 3, 2006, pp. 245-262.

Sмiтн, G., Democratic Innovations, Cambridge University Press, Cambridge, 2009.

TEKIN, B.Ç., «The construction of Turkey's possible EU membership in French political discourse», in Discourse \& Society, vol. 19(6), 2008, pp. 727-763.

De Wilde, P., «No Polity for Old Politics? A Framework for Analyzing the Politicization of European Integration», Journal of European Integration 33, september 2011, pp. 559-575. 